\title{
Women in Diplomacy in Late Eighteenth-Century Istanbul
}

\author{
David Do Paço (iD
}

Department of History, Columbia University, New York, USA, and Centre d'Histoire de Sciences Po, Sciences Po, Paris, France

Email: dd3083@columbia.edu

\begin{abstract}
This article identifies the different roles played by women in the diplomatic corps of the Pera embassies of Christian-ruled states. It focuses on women operating in and from the Habsburg embassy during the last two decades of the eighteenth century, a period marked by the revolutionary wars and the beginning of the 'Eastern Question'. Using a microhistorical approach, this article analyses how women facilitated the embedding of individual members of the diplomatic corps in Pera's diplomatic social scene, the social integration of young diplomats, and the development of the trans-imperial networks of influence upon which diplomats heavily depended. It shifts the focus from states to actors and invites a more systematic development of a diplomatic history based on networks of non-official agents, thus enabling an improved understanding of the family, social, and urban dynamics that led to the development of political elites. This article draws on a set of private sources and parish sources in order to emphasize the role of households in the diplomacy of empires, the agenda of women in the management of patronage and power networks, and the diversity of their social affiliation.
\end{abstract}

When he paid a visit to Malta in 1809 as part of his Grand Tour, Lord Byron was spellbound by a twenty-seven-year-old woman whose portrait he painted for his mother. Born in Istanbul in 1782, Constance Spencer Smith was the daughter of Baron Peter Herbert von Rathkeal, the imperial and royal Internuncio (title held by the representative of the emperor in Istanbul). She grew up in Istanbul, moving in diplomatic and commercial circles. Due to the different socio-cultural legacies that Constance embodied, she belonged not only to the nobility of the Holy Roman Empire, but also to that of the Habsburg empire, as well as the British nobility. In addition, she had origins in both the Jacobite and Albanian diasporas. Prior to becoming the object of Byron's fascination, Constance was already a highly sought-after young woman.

(c) The Author(s), 2021. Published by Cambridge University Press. This is an Open Access article, distributed under the terms of the Creative Commons Attribution licence (http://creativecommons.org/licenses/by/4.0), which permits unrestricted re-use, distribution and reproduction, provided the original article is properly cited. 
Initially promised to a wealthy Levantine family in Santorini, aged sixteen and just a few weeks after Napoleon Bonaparte's invasion of Egypt, she married John Spencer Smith, the British chargé d'affaires to the Ottoman empire. This alliance embodied the reconfiguration of the geopolitical balance in the eastern Mediterranean, which had been disrupted by the French Revolution and the ambitions of the Romanov empire in the Black Sea and the Middle East. Women played an active role in this process of reconfiguration. During the war, Constance pooled the diplomatic resources of the Habsburg and British embassies in Istanbul, negotiating the liberation of prisoners of war, and took over the patronage offered by her father to orientalist scholars such as Thomas Chabert and Joseph Hammer von Purgstall (Hammer), whom he considered to be his protégés. From 1802 onwards, Constance accompanied her husband in the various diplomatic positions he obtained, her involvement being so extensive that Napoleon I accused her of espionage and proclaimed her an enemy. Constance was arrested, and her eventual release generated significant diplomatic tensions, which resulted in her taking refuge in Vienna in the 1810s. She continued to operate within Vienna's business, diplomatic, and literary spheres, and pursued the promotion of her father's former protégés, in particular Hammer, with whom she had been friends as a teenager in Istanbul. Constance's life path invites us to re-examine the place of women in Istanbul's diplomatic circles at the beginning of the 'Eastern Question'. Her life exemplifies the behind-the-scenes contribution that women from Pera made to diplomacy at the cusp of the nineteenth century. By exploring the social and political life of women in Pera in the last two decades of the eighteenth century, this article also highlights the role of informal actors in the foreign policy of empires. It underlines the urban dimension of ancien régime diplomacy and focuses on the local resources used by women in Pera's diplomatic society to develop their influence, to promote their clients, and to support or challenge official agents. It also contributes to the study of trans-imperial agents through research on the history of the family, an approach that has brought to light the role of women in the development of powerful intercultural regional networks. Besides, this article is the history of domestic life, sexuality, and the politics of the intimate. It reveals the sexual and emotional liberty of the young women in the Habsburg and Ottoman empires and explores the different dimensions of their polyamorous and pansexual life, a history of libertinism from the perspective of women in a cross-cultural context. ${ }^{1}$

Women's history has been making a significant contribution to the development of the new diplomatic history that reassesses the contribution of non-official agents. ${ }^{2}$ Non-official agents circulated between courts, cities,

\footnotetext{
${ }^{1}$ Guillaume-Stanislas Trébutien, Notice necrologigue sur Madame Constance Spencer Smith, née Baronne de Herbert Rathkeal (Caen, 1829). See also Revue encyclopédique, ou Analyse raisonnée des productions les plus remarquables, XLI (Paris, 1829), pp. 816-19; Friedrich Edler von Kraelitz-Greifenhorst, 'Rathkeal, Peter Philipp Herbert, Freiherr von', in Historischen Kommission bei der Bayerischen Akademie der Wissenschaften, ed., Allgemeine Deutsche Biographie (56 vols. Leipzig, 1907), LIII, pp. 210-15.

${ }^{2}$ Among the essential contributions in early modern history: Christian Windler, 'Diplomatic history as a field for cultural analysis: Muslim-Christian relations in Tunis, 1700-1840', Historical
} 
and empires and were mobilized occasionally or continuously by diplomatic delegations, ruling houses, and princes. ${ }^{3}$ Their activities question the given idea of a professionalization of diplomacy in the eighteenth century. Numerous studies have, over the last decades, brought to light and analysed the private networks on which official diplomats (ambassadors, ministers, plenipotentiaries, or envoys) relied to establish their influence and carry out negotiations. Within these networks, women have emerged as essential to the maintenance of daily political sociability, the production and circulation of information, the economic management of embassies, and even to political negotiation. As Florian Kühnel recently pointed out, 'early modern diplomacy clearly depended to a large extent on the participation of women'. ${ }^{4}$ It is no longer possible today to define the women moving in diplomatic circles only in relation to the men around them. ${ }^{5}$ This article explores the involvement of three generations of women in diplomacy in the Habsburg, British, and Ottoman empires. Such inquiry allows a better understanding of the deep process of pacification of relations between Vienna and Istanbul and the interdependence of the two empires that was gradually established from 1699. The women of the Palais d'Allemagne - the name given to the Habsburg embassy in Pera-helped to increase the influence of the Habsburgs in the eastern Mediterranean. In Istanbul, from the 1780 s onwards, they contributed to the

Journal, 44 (2001), pp. 79-106; Hillard von Thiesse, 'Diplomatie vom type ancien: Überlegungen zu einem Idealtypus des frühneuzeitlichen Gesandschaftswesens', in Hillard von Thiessen and Christian Windler, eds., Akteure der Außenbeziehungen: Netwerke und Interkulturalität im historischen Wandel (Cologne, Vienna, and Weimar, 2010), pp. 471-504; Eva Dade, Madame de Pompadour: Die Mätresse und die Diplomatie (Cologne, Vienna, and Weimar, 2010); Journal of Early Modern History, 19 (2015/1-2); Jan Hennings and Tracey Sowerby, eds., Practices of diplomacy in the early modern world (London and New York, NY, 2018). See also Karl W. Schweizer and Matt J. Schumann, 'The revitalization of diplomatic history: renewed reflections', International History Review, 19 (2008), pp. 149-86; Lucien Bély, La société des princes: XVIe-XVIIIe siècle (Paris, 1999); and Lucien Bély, Espions et ambassadeurs au temps de Louis XIV (Paris, 1990).

${ }^{3}$ Karin Aggestam and Ann Towns, 'The gender turn in diplomacy: a new research agenda', International Feminist Journal of Politics, 21 (2019), pp. 9-28; Dorothea Nolde, 'Was ist Diplomatie und wenn ja, wie viele? Herausforderungen und Perspektiven einer Geschlechtergeschichte der frühneuzeitlichen Diplomatie', Historische Anthropologie, 21 (2013), pp. 179-98; Corina Bastian, Eva Dade, and Eva Ott, 'Weiblische Diplomatie? Frauen als aussenpolitische Akteurinnen im 18. Jahrhundert', in Corina Bastian, Eva Dade, Hillard von Thiessen, and Christian Windler, eds., Das Geschlecht der Diplomatie: Geschlechterrollen in den Außenbeziehungen vom Spätmittelalter bis zum 20. Jahrhundert (Cologne, Vienna, and Weimar, 2014), pp. 103-14; Jennifer Mori, The culture of diplomacy: Britain in Europe, c. 1750-1830 (Manchester, 2011).

${ }^{4}$ Florian Kühnel, "Minister-like cleverness, understanding and influence in affairs": ambassadresses in everyday business and courtly ceremonies at the turn of the eighteenth century', in Hennings and Sowerby, eds., Practices of diplomacy, pp. 130-46.

${ }^{5}$ Glenda Sluga and Carolyn James, eds., Women, diplomacy and international politics since 1500 (London and New York, NY, 2015). See also Katrin Keller, 'Frauen - Hof - Diplomatie: Die höfische Gesellschaft als Handlungsraum von Frauen in Außenbeziehungen', in Bastian, Dade, Thiessen, and Windler, eds., Das Geschlecht der Diplomatie, pp. 33-50; Kühnel, 'Ambassadresses in everyday business'; Laura Oliván Santaliestra, 'Gender, work and diplomacy in baroque Spain: the ambassadorial couples of the Holy Roman Empire as Arbeitspaar', Gender \& History, 29 (2017), pp. 423-45; and Laura Oliván Santaliestra, Mariana de Austria: imagen, poder y diplomacia de una reina cortesana (Madrid, 2006), pp. 144-51. 
rapprochement between the Habsburg and the British delegations, at a time when the House of Austria was officially a French ally. This rapprochement, undertaken under the ambassadorship of Peter Herbert von Rathkeal between 1779 and 1802, was carried out against the official policy of the Habsburg State Chancellery. It enabled the Habsburg empire to maintain its position in the eastern Mediterranean during the French Revolution as a result of the private connections established in Pera between the Palais d'Allemagne and the British embassy. ${ }^{6}$

This article is therefore also a contribution to the urban and political history of Pera. According to Fariba Zarinebaf, women were 'active players in the urban economy of Istanbul as borrowers, property owners, buyers and sellers, founders of small family endowments, managers and landladies'. ${ }^{7}$ They participated in the management of urban spaces, in the monitoring of neighbourhoods and more broadly in the policing of the city. ${ }^{8}$ Pera was a diplomatic hub, where the majority of the delegations of the Christian powers operating in the Ottoman empire were based. Located to the north of Istanbul, outside the city walls, Pera was the extension of the Galata district where, since the Byzantine period, Genoese and Venetian Roman Catholic merchants had settled. During the Ottoman period, the French, Habsburg, English, and Dutch settled there in turn. The Christian, Jewish, and Muslim economic and political elites of Galata gradually transformed the vineyards of Pera, building a neighbourhood that was socially organized by their respective private patronage. Studying the women that operated in the Habsburg delegation at the end of the eighteenth century allows the Pera economic and social resources used by European diplomats to be explored. This article also examines the urban social life and the sociability of women in diplomacy. It shows how female friendships and societies structured diplomatic life on the Bosphorus and highlights the role that the circulation of women between embassies played in the constitution of diplomatic clienteles, the training of young diplomats, and the recruitment of agents. ${ }^{9}$

\footnotetext{
${ }^{6}$ Many studies have demonstrated that in the first half of the eighteenth century, Habsburg agents established an original diplomatic system based on far-reaching personal patronage in Ottoman society: David Do Paço, 'A social history of trans-imperial diplomacy in a crisis context: Herbert von Rathkeal's circles of belonging in Pera, 1779-1802', International History Review, 42 (2019), pp. 981-1002; Robert-Tarek Fischer, Österreich im Nahen Osten: die Grossmachtpolitik der Habsburgermonarchie im Arabischen Orient, 1633-1918 (Cologne, Vienna, and Weimar, 2006); Rudolf Agstner and Elmar Samsinger, eds., Österreich in Istanbul: K. (u.) K. Präsenz im Osmanischen Reich (Munster, 2010). See also Paula Sutter Fichtner, Terror and toleration: the Habsburg empire confronts Islam, 1526-1850 (London, 2010); and Karl A. Roider, Austria's Eastern Question, 1700-1790 (Princeton, NJ, 1982).

${ }^{7}$ Fariba Zarinebaf, 'From mahalle (neighborhood) to the market and the courts: women, credit, and property in eighteenth-century Istanbul', in Jutta Gisela Sperling and Shona Kelly Wray, eds., Gender, property, and law in Jewish, Christian, and Muslim communities in the wider Mediterranean, 13001800 (London and New York, NY, 2009), p. 232.

${ }^{8}$ Michael Talbot, 'A Jacobite lady in Constantinople: the story of Lady Mary Gerard of Gerard's Bromley', Staffordshire History, 53 (2011), pp. 3-14; Betül Başaran, Selim III, social control and policing in Istanbul at the end of the eighteenth century (Leiden and Boston, MA, 2014), pp. 168-213.

${ }^{9}$ E. Natalie Rothman, The dragoman renaissance, diplomatic interpreters and the routes of orientalism (Ithaca, NY, 2021); Fariba Zarinebaf-Shahr, Mediterranean encounters trade and pluralism in early
} 
The study of women in diplomacy in Istanbul at the end of the eighteenth century contributes to family history in a broader perspective. Laura Oliván Santaliestra, Corina Bastian, and Florian Kühnel have all highlighted the division of roles between ambassadors and their wives in the seventeenth and eighteenth centuries. Marriages were a crucial combination of resources for diplomats' careers. In the Christian embassies of eighteenth-century Pera, this was also true for those holding secondary diplomatic positions such as secretaries and interpreters. Despite the efforts of France, Austria, and the United Provinces to train their own agents, the Roman Catholic families of Pera, subjects of the Ottoman sultan, retained an important influence over the European diplomatic corps. Until the nineteenth century, they were associated, through marriages, with the diplomacy of the Christian powers in Istanbul. This influence was based on the patronage of the Catholic parishes of Pera, such as Saint Mary Draperis, of which the Internuncio had been the protector since 1739. This article cannot, however, be limited to considering women only in their status as wives. Mothers, wives, sisters, and daughters, but also lovers and unofficial partners, were both agents and resources of diplomatic action, as the entourage of Peter Herbert von Rathkeal demonstrates. Moreover, women in diplomacy more generally cannot be considered only as political instruments. They developed their own powerful agendas and demonstrated their social, moral, and emotional liberty. Depending on their age and status, they played different roles in the family diplomatic enterprise. They controlled access to social worlds and managed their own clienteles, which they freely associated with or in some cases were imposed on them. They were the foundation stones of political alliances, sources of information, and informal agents who worked as much for the success of court diplomacy and the interests of the family to which they belonged as for the interests of the state and the people they served or represented. ${ }^{10}$

Multiple sources document the history of women in diplomacy in Istanbul at the end of the eighteenth century. Some are unpublished and others call for a complete re-examination of their influence and involvement. The private collections of Constance and John Spencer Smith at the Rice University Library in

modern Galata (Oakland, CA, 2017); John Paul Gohbrial, The whispers of cities: information flow in Istanbul, London, and Paris in the age of William Trumbull (Oxford, 2013); Mariya Vladimirovna Amelicheva, 'The Russian residency in Constantinople, 1700-1774: Russian-Ottoman diplomatic encounters' (D.Phil. thesis, Georgetown University, 2016), pp. 149-293; Edem Elden, ed., Recherches sur la ville ottomane: le quartier de Galata, Istanbul (Istanbul, 1991); and Oliver Jens Schmitt, Levantiner: Lebenswelten und Identitäten einer ethnokonfessionelle Gruppe im osmanischen Reich im 'langen 19. Jahrhundert' (Munich, 2005), pp. 127-41.

${ }^{10}$ Christopher H. Johnson, David Warren Sabean, Simon Teuscher, and Francesca Trivellato, eds., Transregional and transnational families in Europe and beyond: experiences since the middle ages (New York, NY, and Oxford, 2011); Emma Rothschild, The inner life of empire: an eighteenth-century history (Princeton, NJ, 2011); Antoine Gautier and Marie de Testa, Drogmans et diplomates auprès de la porte ottomane (Istanbul, 2003). See also David Do Paço, 'The political agents of Muslim rulers in central Europe in the eighteenth century', in David Thomas and John Chesworth, eds., ChristianMuslim relations: a bibliographical history, XV: Central and Eastern Europe (1700-1800) (Leiden, 2020), pp. 39-55; and Mariusz Kacka, 'Pashas and nobles: Paweł Benoe and Ottoman-Polish encounters in the eighteenth century' (D.Phil. thesis, European University Institute, 2019). 
Houston, Texas, allow us to understand better Constance's personal life, the social configuration in which she grew up during the revolutionary period, and the diversity of her affiliations to and between the Habsburg, Ottoman, and British empires. ${ }^{11}$ John Spencer Smith's private correspondence with the Foreign Office in London also sheds light on the role of informal agents, including women, in the strengthening of ties between the Habsburg and British diplomatic corps, particularly in the $1790 \mathrm{~s}^{12}$ In addition, Peter Herbert von Rathkeal's voluminous private correspondence with his patron in Vienna, the Vice State Chancellor Count Johann Philipp von Cobenzl, allows the way that Constance and her sister Fanny were raised to be contextualized in the political society of Pera, where women were omnipresent. Peter Herbert von Rathkeal's letters regularly referred to the actions of his mother and sisters and the ways in which their respective influences sometimes became obstacles for his diplomatic action. ${ }^{13}$ Finally, the archives of Saint Mary Draperis help to reconstitute networks, to identify the role that women played in them, and the private strategies that they developed. The parish archives are considered here to be diplomatic archives in their own right insofar as a study of diplomacy focused on female actors makes it impossible to distinguish between what were the public affairs of an embassy and what were the private affairs of an agent and his family. ${ }^{14}$

The Palais d'Allemagne was a rhizome of Pera's female society. Constance grew up there in a polynuclear family within a household that was well connected with the European and Istanbul diplomatic milieu. Women deployed their influence in many ways, and took advantage of, supported, and sometimes transformed this milieu. They represented and sometimes led parties whose agendas could be aligned with those of the ambassadors, but which could equally form obstacles to their action. Women could distinguish themselves within Pera's diplomatic milieu by asserting an intellectual, moral, and sentimental libertinism based on their upbringing, at a time when this was being repressed in much of the rest of Europe. Such freedom illustrates both the influence and independence of women in Pera's diplomatic society.

\section{II}

Constance Herbert von Rathkeal was born in Pera in 1782. Like many women involved in diplomacy in eighteenth-century Istanbul, she operated within a household, i.e. a relational community consisting of her parents, her relatives,

\footnotetext{
${ }^{11}$ Rice University Library (RUL), Woodson Research Center (WRC), MS 256 William Sidney Smith papers.

${ }^{12}$ The National Archives (TNA), Foreign Office (FO), 78-9; see also British Library, Manuscript Collection, Add MS 59032.

${ }^{13}$ Österreichisches Saatsarchiv (OeStA), Haus- Hof- und Staatsarchiv (HHStA), Staatenabteilungen, Türkei IV, 18-19; Eric R. Dursteler, Renegade women: gender, identity and boundaries in the early modern Mediterranean (Baltimore, MD, 2011).

${ }^{14}$ Parish registers of Constantinople (PRC), Sainte Marie Drapéris (StMD), Livre unique des Germains (LUG). See also E. D’Aleggio Dalessio, 'La communauté latine de Constantinople au lendemain de la conquête ottomane', Revue d'études byzantines, 187 (1937), pp. 309-17; and Laura Elizabeth Binz, 'Latin missionaries and Catholics in Constantinople 1650-1760: between local religious culture and confessional determination' (D.Phil. thesis European University Institute, 2013).
} 
and their respective servants and protégés. Women helped this household to connect and embed in the local urban society. From the household, they developed solidarities across diplomatic corps. Within the household, they influenced diplomats on behalf of a minister or a clientele.

The women of Pera's diplomatic milieu were characterized by their very complex backgrounds which frequently entangled several empires. Constance was the perfect example. On her mother's side, she came from the lower nobility of the Holy Roman Empire and was also the granddaughter of a particularly influential diplomat in the service of the Emperor Joseph II. Through her father, Constance was a subject of the House of Austria, i.e., of Joseph II, Leopold II, and Francis II/I. This gave her and her siblings a formal status in both the Holy Roman Empire and the Habsburg empire, and the titles, lands, and incomes that were linked to this status. However, Peter Herbert von Rathkeal was himself born in Pera in 1755 to a mother from the Albanian diaspora, and a father from the Jacobite diaspora. These two diaspora heritages forged Constance's Roman Catholic identity. In addition, Peter Herbert von Rathkeal was the patron of the church of Saint Mary Draperis, where the most influential Roman Catholic families of Pera such as the Testas, the Pisanis, and the Chaberts were baptized, married, and buried. Constance's roots in the Jacobite diaspora were further reinforced by her marriage in 1798 to John Spencer Smith, whose family was also Roman Catholic. This marriage made Constance the sister-in-law of William Sidney Smith, commodore of the Royal Navy in the Eastern Mediterranean. Constance thus extended the social surface of her family even further. Her marriage to Spencer Smith allowed her to reconnect formally with the British crown. ${ }^{15}$

Constance's trans-imperial background reflected the cultural diversity of the women who lived and operated in the different embassies of Istanbul. Women were particularly numerous in the Palais d'Allemagne. The Habsburg embassy was in effect a household organized by Peter Herbert von Rathkeal and his wife Maria Anna von Collenbach, who formed a central couple. ${ }^{16}$ When pregnant with her first child, Maria Anna travelled from Vienna to Istanbul via the Danube river valley and then the Balkans. She gave birth to her daughter Fanny in 1779, and then to Constance in 1782, followed by Henry Constantin in 1785 . The couple deliberately chose Christian names that perpetuated the family's British roots. ${ }^{17}$ The family lived in the building that initially housed the Habsburg embassy, a house in poor condition rented from a Jewish Ottoman landlord in Istanbul. In 1783, the family moved to the monastery of the Trinitarian Order in Pera, which formally became the new Palais d'Allemagne. ${ }^{18}$

\footnotetext{
${ }^{15}$ RUL, WRC, WSSP, 1/23-7; Do Paço, 'A social history of trans-imperial diplomacy', pp. 987-90.

${ }^{16}$ Philipp Cobenzl, 'Souvenirs de différentes époques de ma vie', in Alfred Knight von Arneth, ed., Graf Philipp Cobenzl und seine Memoiren (Vienna, 1885), pp. 109-10.

${ }^{17}$ Peter Herbert von Rathkeal also had two brothers named Thomas and John. This was all the more important as in 1781 he was awarded the title of earl of Pembroke, which had been revoked from his father when he left Ireland.

${ }^{18}$ Herbert to Cobenzl, Pera, 4 Apr. 1780, OeStA, HHStA, Staatenabteilungen, Türkei V, 18, fo. 75v; Do Paço, 'A social history of trans-imperial diplomacy', pp. 981-2.
} 
Constance and her siblings grew up with their parents in a polynuclear family, with three generations living under the same roof. The various married couples and the multiple generations of women who composed the household of the Palais d'Allemagne provided the children with access to different local social milieus. In addition to Maria Anna and Peter Herbert von Rathkeal, Emmanuel Isidore von Tassara - who was the Habsburg resident in Pera between 1774 and 1779-and his wife-Herbert's sister-lived with their daughter in the Palais d'Allemagne. The Tassaras unofficially served Herbert von Rathkeal, in particular helping him to socialize within diplomatic circles. Herbert briefly evoked that he had a second sister, a nun who also lived in the Palais d'Allemagne ${ }^{19}$ and his mother, Francesca Skanderbeg. With the exception of Maria Anna, all of the women in the family were born and raised in Pera. On the death of her husband in the mid-1750s, Francesca Skanderbeg had placed herself under the protection of the Internuncio Heinrich von Penckler, which can be interpreted as illustrating the strength of the family connection with the Habsburg empire. ${ }^{20}$ While her four sons left Istanbul as teenagers to pursue careers in the service of the Roman Catholic church, the Habsburg empire, and the Polish-Lithuanian Commonwealth, her daughters remained with her in Pera. As we shall see below, their presence played a part in the appointment of Herbert in Istanbul, due to the multiple social milieus to which they had access. $^{21}$

Other women, in particular domestic servants, were notable and played an essential role in the smooth running of the Habsburg embassy. Herbert von Rathkeal wrote:

I cannot dismiss any of the people working here, as they are all indispensable given our life here. I need four laundresses for the household; those here are not like those in Vienna, and I am even provided with [female] servants, because of accidents, of the very frequent warnings for plagues, and because of the yearly migration between town and country. ${ }^{22}$

In 1719, Mary Wortley Montagu - whose husband had been the British ambassador in Istanbul from 1716 - mentioned the large number of female domestic workers around her and the linguistic, religious, and cultural

\footnotetext{
19 'J'ai plus de 50 bouches à nourrir, y compris ma mère et ma sœur, fille, ainsi que $\mathrm{M}$. et $\mathrm{Me}$ Tassara, leur fille et trois domestiques.' Herbert to Cobenzl, Pera, 2 June 1780, OeStA, HHStA, Staatenabteilungen, Türkei V, 18, fo. 91r.

${ }^{20}$ Heinrich von Penckler remained in Pera between 1740 and 1755 and provided the Habsburg administration with an extremely rich journal containing the details of his mission: OeStA, HHStA, Staatenabteilungen, Türkei V, 16; see also David Do Paço, L'Orient à Vienne au dix-huitième siècle (Oxford, 2015), pp. 151-72.

${ }^{21}$ On the Albanian diaspora in Istanbul and the Ottoman empire, Noel Malcolm, Agents of empire: knights, corsairs, Jesuits and spies in the sixteenth-century Mediterranean world (Oxford, 2015). Ainslie to Hillsborough, 12 Apr. 1782, TNA, FO, 78/3, fo. 81r; OeStA, HHStA, Staatskanzlei, Orientalische Akademie (OA), 55, fo. 48r; Cobenzl, 'Souvenirs', pp. 72-3.

${ }^{22}$ Herbert to Cobenzl, Pera, 2 June 1780, OeStA, HHStA, Staatenabteilungen, Türkei V, 18, fo. 91r, translated from French.
} 
diversity of the group they formed. ${ }^{23}$ In 1779 , the Tassara couple had three handmaids. Maria Anna and Francesca had as many respectively. In addition, a midwife accompanied Maria Anna from Vienna and assisted in the births of Fanny, Constance, and Henry Constantin. They all participated in the domestic functioning of the Palais d'Allemagne and thus in its representative function with regard to the Habsburg empire. Servants were also social and cultural intermediaries who acted as a link between the embassy and the city. They were particularly rich sources of information for the embassy, informing their patrons about rumours that were circulating in the city as well as propagating rumours of their own. ${ }^{24}$ They provided the Habsburg embassy with invaluable information about the social climate of the city, an important political issue for diplomats, as demonstrated by the fire of 1799, which occurred after a popular revolt and the burning of a bakery, events which narrowly avoided burning Pera to the ground. ${ }^{25}$

The household in which Constance was raised was indeed larger than her immediate family. It included the employees and protégés who also lived in the Palais d'Allemagne. Among these protégés were the interpreters in oriental languages (Sprachknaben) who, after receiving theoretical training at the Oriental Academy in Vienna, were sent to Pera for practical language and business training. ${ }^{26}$ Their stay at the Palais d'Allemagne was often marked by their marriages to the daughters of the Roman Catholic families of Pera. These families provided the European embassies with the interpreters and legation secretaries. Herbert von Rathkeal himself supervised the organization of these

\footnotetext{
${ }^{23}$ Mary Wortley Montagu, Letters of Lady Mary Wortley Montagu: written during her travels in Europe, Asia, and Africa (Paris, 1800), p. 162. The Russian residency shows a comparable situation. See 'Upon Resident Veshniakov's death, his choice of wife again proved to be unwise for the well being of the mission. Indeed, the suite of Madame Tarsia-Veshniakov, including herself, consisted of seventeen people: two small children, one female relative, one female servant (kamardiner), a wet nurse, one old lady, one woman, one young lady, one male servant/valet (kamardiner), two lackeys, one çuhadar who made coffee, one stableman, a saka (vodonosets), and two cleaning ladies (portomoiki). All of them lived off of the mission's budget.' Amelicheva, 'The Russian residency', pp. $180-1$.

${ }^{24}$ Daniel Roche, Le peuple de Paris: essai sur la culture populaire au XVIIIe siècle (Paris, 1981); Bridget Hill, Servants: English domestics in the eighteenth century (Oxford, 1996); The History of Family, special issue, ed. Antoinette Fauve-Chamoux and Richard Walls, 'The domestic servants in a comparative perspective', 10/4 (2005).

${ }^{25}$ Before Constance's birth and the marriages of his Sprachknaben (German students in oriental languages) 'j'ai une quinzaine de femmes dans ma maison', Herbert to Cobenzl, Istanbul, 3 Feb. 1780, OeStA, HHStA, Staatenabteilungen, Türkei V, 18, fos. 57v, 58r; Smith to Granville, Istanbul, 18 Mar. 1799, TNA, FO, 78/21, fos. 206r-209v.

${ }^{26}$ Hana Navrátilová and Roman Míšek, 'The Oriental Academy, birth of a new era of Austrian diplomacy in the orient', Archiv orientální, 71 (2003), pp. 199-204; Oliver Rathkolb, ed., 250 Jahreven der Orientalischen zur Diplomatischen Akademie Wien (Innsbruck, 2004); Ersnt Dieter Petritsch, 'Interkulturelle Diplomatie zwischen Habsburgern und Osmanen: Fragen und Probleme', in Brigit Tremml-Werner and Eberhard Crailsharm, eds., Audienzen und Allianzen. Interkulturelle Diplomatie in Asien und Europa vom 8. bis 18. Jahrhundert (Vienna, 2015), pp. 184-200; and David Do Paço, 'Patronage and expertise: the creation of a trans-imperial knowledge, 1719-1748', in Lothar Schilling and Jakob Vogel, eds., The transnational cultures of expertise: circulating state-related knowledge in the eighteenth and nineteenth centuries (Oldenbourg, 2019), pp. 48-61.
} 
marriages. For example, in 1786, the interpreter Ignaz von Sturmer married Elisabeth de Testa, the daughter of Herbert von Rathkeal's secretary of legation. The Testas were an old Roman Catholic family from Genoa, which had been based in Pera since the Byzantine period and had successfully maintained their social status and increased their influence during the Ottoman era. Elisabeth and her husband lived in the Palais d'Allemagne before moving to Vienna in 1787. In Vienna, Sturmer became court secretary for oriental languages. His marriage to Elisabeth granted him direct and indispensable access to Pera's Roman Catholic milieu, and through this, access to the Ottoman empire. In 1794, 1800, and 1801, Peter Herbert von Rathkeal married three of his Sprachknaben to three daughters - Caterina, Maria, and Anna-of the first interpreter of the British embassy, Nicolò Pisani. By moving into the Palais d'Allemagne, they sealed not only the alliance between the emperor and the king of England in the middle of the revolutionary wars, but also the common private interests of Peter Herbert von Rathkeal and John Spencer Smith (who had married Constance in 1798). Eventually, in 1802, following the death of Herbert von Rathkeal, Sturmer was appointed Internuncio. ${ }^{27}$

After the family and the household, the Christian diplomatic milieu of Pera was a third circle of socialization for Constance and her siblings, where they learned the codes of an international political elite. From the end of the eighteenth century, Pera political circles participated in the training and social integration of expatriate families whose members, despite their different origins, together formed a milieu that shared social codes and economic interests. The young Antoine-Baudoin-Gisbert Dedem van Gelder - son of the representative of the United Provinces in Istanbul - also grew up in Pera and regularly met Constance, her siblings, and their mother. In his memoirs, he described the narrowness of Pera's diplomatic society and the fact that the children came and went freely in the houses of the different ambassadors. He evoked, for example, the affection he felt for the French ambassador Marie-Gabriel-Florent-August Choiseul-Gouffier and for the British ambassador Robert Ainslie, at whose homes he often played. He considered himself to be 'treated by both as a child of the household,. ${ }^{28}$ Dedem van Gelder also referred to his familiarity with the

\footnotetext{
${ }^{27}$ PRC, StMD, LUG; Christoph Mentschl and Antonio Schmidt-Brentano, 'Stürmer Ignaz Frh. von', in Österreichisches Biographisches Lexikon (15 vols., Vienna, 2010), XIII, p. 445; Constantin von Wurzbach, Biographisches Lexikon des Kaisertums Österreich (60 vols., Vienna, 1882), XLIV, pp. 38-9; Gauthier and Testa, Drogmans et diplomates, pp. 380-8. See also Alexander H. de Groot, 'Dragomans' careers: the change of status in some families connected with the British and Dutch embassies at Istanbul, 1785-1829', in Alastair Hamilton, Alexanser H. de Groot, and Maurits H. van den Boogert, eds., Friends and rivals in the East: studies in Anglo-Dutch relations in the Levant from the seventeenth to the early nineteenth century (Leiden, 2000), pp. 223-46; Pascal Firges, French revolutionaries in the Ottoman empire: diplomacy, political culture, and the limiting of universal revolution, 1792-1798 (Oxford, 2017).

${ }^{28}$ Antoine Dedem van Gelder, Mémoires du general de Dedem de Gelder, 1774-1825 (Paris, 1900), p. 23. See also Chantal Grell, 'Les ambigüites du philhellenisme: l'ambassade du comte de Choiseul Gouffier auprès de la Sublime Porte (1784-1792)', Dix-huitième siècle, 27 (1995), pp. 223-35; Frédéric Barbier, Le rêve grec de Monsieur de Choiseul: les voyages d'un Européen des Lumières (Paris, 2010); Ali Ihsan Bagis, Britain and the struggle for the integrity of the Ottoman empire: Sir Robert Ainslie's embassy to Istanbul 1776-1794 (Istanbul, 2010).
} 
children of the Herbert von Rathkeals. His mother had become friends with Maria Anna, who would visit her with Fanny and Constance. He remarked that Maria Anna was raising her daughters herself, which was considered abnormal by the standards of the European aristocracy. This upbringing was above all a social education. For the Herbert von Rathkeal children, it was a question of making their social rank known and gaining the appropriate recognition. It was also about giving them the means to hold this social position in diplomatic society. This was all the more important as Dedem van Gelder described the Herbert von Rathkeal family as arriviste, adding:

the aggressive character and shrill voice reminding me of an office boy, which was Baron von Herbert-Rathkeal's first social condition, was not fit for a Versailles courtier. His wife had precious qualities - she became friends with my mother - yet, her arrogant tone and German etiquette could make her insufferable. After the death of her husband, she was called to the Court of the Great Dukes of Tuscany to take care of the education of young princesses. ${ }^{29}$

Learning the codes through respective visits to embassies, creating familiarity among children from different diplomatic corps, and allowing teenagers to take part in official receptions helped to insert young women into this diplomatic society. Joseph Hammer von Purgstall recalled meeting Constance for the first time in 1799 at her father's table, where she distinguished herself in a 'friendly and witty ${ }^{10}$ manner while discussing current political affairs. By then, she was already married to John Spencer Smith, who had been promoted to British minister plenipotentiary. Constance's marriage did not, however, remove her from her family, with whom she continued to live on a partial basis. Through his marriage with Constance, Spencer Smith had become a member of the Herbert von Rathkeal household. In 1799, such was his familiarity with Constance's father that he was able to safeguard the British cipher and its seals in the Palais d'Allemagne while the fire burned the British embassy to the ground. ${ }^{31}$

Women clearly occupied a prominent position within and between embassies. Far from being reduced to the persona of the ambassador's wife, the female presence was embodied over several generations and at several levels of the embassy, from the central couple to the servants and the intermediate level of agents. Women were present in the family, the household and in the urban society of Pera.

\section{III}

The Palais d'Allemagne was only one rhizome of the feminine milieu of Pera's political society, which was a hierarchical milieu fraught with tensions. Indeed, the Habsburg embassy was a social and political arena in which

\footnotetext{
${ }^{29}$ Dedem van Gelder, Mémoires, p. 28, translated from French.

${ }^{30}$ Joseph Freiherr von Hammer-Purgstall, Erinnerungen aus meinem Leben, 1774-1852 (Vienna and Leipzig, 1940), p. 32.

${ }^{31}$ Smith to Granville, Istanbul, 18 Mar. 1799, BNA, FO, 78/21, fos. 206v-207r.
} 
competition for power and control over the financial resources that flowed from it was played out. Influential and complex female figures emerged from such competition. They divided, reconfigured, and managed the household.

During the last decades of the eighteenth century, such influential women exerted considerable control over Pera's political and social life. Some, like Catherine Chabert (the wife and then the mother of two different Neapolitan minister plenipotentiaries), had an international reputation, and the support of such women was crucial to achieving diplomatic goals. Dedem van Gelder described Catherine Chabert as 'a female master, she ran both politics and her household'. ${ }^{32}$ Born in 1725 in Pera, Chabert was from a family of Provençal merchants that had settled in Istanbul at the end of the seventeenth century. The Chaberts occupied a growing place in the diplomatic circles of Pera. Jean, Catherine's brother, was the dragoman of both the king of Poland and the king of the Two Sicilies. Catherine married the Neapolitan minister plenipotentiary in 1750, and in 1774 she married her daughter to the French ambassador in Istanbul. ${ }^{33}$ She also recommended her nephew, Thomas Chabert, to Peter Herbert von Rathkeal, a move that paved the way for him to join the prestigious Oriental Academy in Vienna in 1779, and subsequently enter into the service of the Habsburg Chancellery of State. ${ }^{34}$ By the 1820s, Thomas Chabert was at the heart of the Viennese orientalist circle, along with Hammer and Constance Spencer Smith. Maria Anna von Collenbach was another case in point. Her father was one of the most influential advisers to the Habsburg chancellor of state, and her brother was the secretary of legation of the Habsburg embassy to the Danish court. Maria Anna took advantage of her brother's connections in Denmark. Indeed, in Pera, she employed Frederick Hübsch, the Danish secretary of legation in Istanbul, as her personal trader. Hübsch, through his two successive marriages, was connected to the Palais d'Allemagne, and Maria Anna eventually recommended him to her husband and obtained for him - due to the loans he procured for the Habsburg court - the title of count of Grossthal. ${ }^{35}$ Both Maria Anna von Collenbach and Catherine Chabert promoted their respective family interests. They benefited from their position in Pera's diplomatic circles and from the

\footnotetext{
32 'Maitresse femme, elle dirigeait aussi bien la politique que son ménage', Dedem van Gelder, Mémoires, p. 39. See also Gautier and Testa, Drogmans et diplomates, p. 228.

${ }^{33}$ Wilhelm von Ludolff (1712-93), an aristocrat from central Germany who obtained several diplomatic appointments and was minister plenipotentiary for the king of Naples. Dedem van Gelder, Mémoires, pp. 39-41. See also PRC, StMD, LUG, 1725, 1750, 1793.

${ }^{34}$ Herbert to Cobenzl, Pera, 3 Oct. 1779, OeStA, HHStA, Staatenabteilungen, Türkei V, 18, fo. 23r; Herbert to Cobenzl, Pera, 3 Dec. 1779, ibid., fo. 51r-v; Antoine Gautier, 'Thomas von Chabert-Ostland (1766-1841), orientaliste autrichien et sa famille', Le Bulletin (1997), pp. 67-90; OeStA, HHStA, Orientalische Akademie (OA), 56, fos. 215r-216v.

${ }^{35}$ Although his father immigrated from Saxony in Istanbul, Anton Friedrich Hübsch von Grossthal was very well connected with the Roman Catholic families and the local diplomatic milieu. He married in turn in 1762 Maria Mormmarz, the daughter of a Habsburg dragoman, and in 1779 Caterina Timoni, the daughter of a British dragoman. From his first marriage, his daughter Caterina married Jakob von Wallenburg, one of the Habsburg Sprachknaben. PRC, StMD, LUG, 1741, 1762, 1779, and 1814.
} 
private financial investments they made. They were also responsible for a part of their respective embassies' finances. In running their own enterprises, they ensured the financial autonomy of the embassy and they also derived economic benefit from it. ${ }^{36}$

Catherine Chabert stands out from the other influential women of Pera by her presence in official diplomatic sources related to her quasi-official political status. Operating in conjunction with her husband, she acted in the service of the king of Naples and in the interests of the Chaberts in equal measures. Maria Anna von Collenbach maintained a regular correspondence with her father, Gabriel Heinrich von Collenbach. This correspondence was essential because Maria Anna managed her own family's domestic affairs, and ensured her involvement in Viennese social life. Moreover, Maria Anna's private letters differed from her husband's correspondence, which for the most part was concerned only with business. This division of tasks was attested to in Madrid during the War of the Spanish Succession (1700-14) where relations between courts 'were organized in parallel channels of communication and ongoing connections were ensured both by the correspondence of office holders and of "informal" actors' and where 'political proceedings took place in networks in which both men and women were actors' ${ }^{37}$ The role that Maria Anna von Collenbach played in relation to Peter Herbert von Rathkeal can also be compared to that of Mary Wortley-Montagu in relation to her husband Sir Edward Wortley-Montagu. The British delegation in early eighteenth-century Pera was not led by an ambassador but rather by a household involved in 'economic and social joint ventures. Regardless of their social position, husband and wife managed their household together and both undertook fundamental tasks for common objectives, ${ }^{38}$ although there may have been a gendered division of labour, as internal household matters were managed by women and external matters by men. ${ }^{39}$

In general, and as the three Pisani sisters who married the Habsburg students in oriental languages illustrated, the influential women of Pera were married to men occupying secondary positions in Christian embassies: secretaries, dragomans, and interpreters. With the exception of Mary Wortley-Montagu, Catherine Chabert, and Constance Spencer Smith, women

\footnotetext{
${ }^{36}$ Herbert to Cobenzl, Pera, 2 June 1780, OeStA, HHStA, Staatenabteilungen, Türkei V, 18, fo. 91r; Herbert to Cobenzl, Pera, 26 May 1781, ibid., fo. 163r-v; Herbert to Cobenzl, Belgrade, 26 June 1781, ibid., fo. 165r; Herbert to Cobenzl, Belgrade, 16 Sept. 1780, ibid., fo. 120r. See also PRC, StMD, 1741, 1762, and 1779; Dedem van Gelder, Mémoires, p. 40; Ainslie to Hillsborough, 12 Apr. 1782, TNA, FO, $78 / 3$, fo. $82 \mathrm{v}$. Here, the British ambassador points out that this practice was introduced by Baron Thugut at his embassy in 1770-4. The porosity that existed between the diplomatic and commercial worlds in Istanbul had persisted since the sixteenth century, as shown in Eric Dursteler, Venetians in Constantinople: nation, identity, and coexistence in the early modern Mediterranean (Baltimore, MD, 2006), pp. 23-60.

${ }^{37}$ Corina Bastian, 'Paper negotiations: women and diplomacy in the early eighteenth century', in Sluga and James eds., Women, diplomacy and international politics, p. 109.

${ }^{38}$ Kühnel, 'Ambassadresses in everyday business', p. 131.

${ }^{39}$ Corina Bastian, Verhandeln in Briefen: Frauen in der höfischen Diplomatie im frühen 18. Jahrhundert (Cologne, Vienna, and Weimar, 2013); Kühnel, 'Ambassadresses in everyday business', pp. 136-41.
} 
were rendered almost systematically invisible in the official diplomatic archives. Even Maria Anna von Collenbach did not appear in her husband's diplomatic dispatches. Only a few private collections, such as those of the Herbert von Rathkeal family, allow us to study these women in more detail. Their presence was also documented in parish archives. The mention of godparents on baptism certificates and the mention of marriage witnesses suggests the social influence of certain women. Caterina Pisani, for example, was baptized in 1774 in the church of Saint Mary Draperis. Her godmother was Victoria Pisani, the widow of Thomas, the eldest of the Herbert von Rathkeal siblings who died of the plague in $1760 .{ }^{40}$ Caterina Pisani married a young language student from the Palais d'Allemagne in the church of Saint Mary Draperis, with Maria Anna von Collenbach, Peter Herbert von Rathkeal, and Constantin Deval, the king of Spain's dragoman, as witnesses. Caterina Pisani's father was the first dragoman of the British embassy, and he also served as an agent of Catherine II. Originating from Genoa, the Pisani family had been present in Pera since the thirteenth century and had long been affiliated to other Roman Catholic families such as the Testas and the Tominis. ${ }^{41}$

Women's political influence thus lay within the social space of the household, overlapping with the embassy and the city. The private correspondence of the British ambassador Robert Ainslie and that of Peter Herbert von Rathkeal particularly emphasized the political role of Francesca Skanderbeg (Herbert von Rathkeal's mother). As a Roman Catholic from Pera, she had facilitated her husband's entry into the affairs of the Ottoman empire. Through the contacts she developed with Habsburg agents in Pera, she was able to guarantee her children's careers, and was still managing the family business in the 1780s, by which time she was described by her son as being an 'old and venerable woman'. As Peter Herbert von Rathkeal confessed in 1782: 'I willingly submit to constantly having my mother and sister at my table and in my society. ${ }^{42}$ To a certain extent, Francesca Skanderbeg was even treated as an official agent of the Palais d'Allemagne. Herbert von Rathkeal explained how she was remunerated:

From my own pocket, I give my mother an allowance of 600 florins to which are added rich cloths and other presents given by Mrs Herbert. Thanks to this woman, and even more easily had I added two hundred piasters, I could have been excused from their [his mother and sister's] constant presence, and would have been allowed to do so by M. de Ludolff [the Neapolitan minister and Catherine Chabert's husband], in whose household one never meets either his brother or his sister-in-law during assemblies or private dinners. ${ }^{43}$

${ }^{40}$ PRC, StMD, 3/408, 25/101, and LUG.

${ }^{41}$ Michael Talbot, British-Ottoman relations, 1661-1807: commerce and diplomatic practice in eighteenth-century Istanbul (Woodbridge, 2017), pp. 152 and 211; Gautier and Testa, Drogmans et diplomates, pp. 162, 312-14.

${ }^{42}$ Herbert to Cobenzl, Pera, 25 Apr. 1782, OeStA, HHStA, Staatenabteilungen, Türkei V, 18, fo. $231 \mathrm{v}$.

${ }^{43}$ Ibid., fos. 231v-232r, translated from French. 
The sum of 600 florins was the same as the annual income of the students in oriental languages, who also lived in the Palais d'Allemagne and received regular gifts. In Francesca Skanderbeg's case, this remuneration was in recognition of the advice she offered, the information she procured, and the active role she played among those members of Pera's diplomatic elite who served the emperor's representative to the Ottoman empire. ${ }^{44}$

In addition, Francesca Skanderbeg led a party that defended her interests inside the Palais d'Allemagne. Like Catherine Chabert and Maria Anna von Collenbach, she protected her clients and sought to promote their careers. Indeed, control over the Palais d'Allemagne's diplomatic positions generated competition within the Viennese court due to the income that could be derived from them. As Dedem van Gelder (Constance's childhood friend) pointed out, this competition also existed within other diplomatic corps, such as the Venetian embassy. In order to avoid such tensions, the Venetian Senate appointed new representatives every three years to ensure that as many families as possible benefited from the incomes derived from the position. ${ }^{45}$ Herbert von Rathkeal himself confessed to expecting an income of 100,000 guilders after ten years in office. When the secretary of legation position at the Palais d'Allemagne became available, Herbert von Rathkeal, on the recommendation of his mother, put Giovanni Pangalli's name forward to the Habsburg Chancellery of State. He described Pangalli as a brilliant young man who had fallen from grace in the Polish embassy due to matters of morality. Pangalli had been unemployed since his dismissal from the Polish embassy and Herbert von Rathkeal entrusted him with occasional assignments. He eventually admitted that his trust in Pangalli was due to the fact that the young man was a relative of his mother. ${ }^{46}$

The different private interests within the Habsburg embassy could lead to long-simmering conflicts. Herbert von Rathkeal involved not only his mother but also his sister in various diplomatic meetings in which he took part. Between 1774 and 1779, they played the role of 'ambassadress' alongside Emanuel Isidore von Tassara. The arrival of Peter Herbert von Rathkeal in Pera in 1779 deprived his sister of a position of prestige, and her protégés of the direct and indirect incomes attached to Tassara's diplomatic position. These tensions led Herbert von Rathkeal to request that the Tassara couple be returned to Vienna:

\footnotetext{
${ }^{44}$ Providing the detail of his budget: 'le casuel consiste en présens faits en nature, des étoffes, des pelisses, des vins, des provisions etc. On les reçoit d'un côté, on les donne ou consomme de l'autre. C'est ainsi que de ma pelisse de zibeline du Grand Seigneur j'ai fait présent à M. Testa', Herbert to Cobenzl, Pera, 26 May 1781, OeStA, HHStA, Staatenabteilungen, Turkei V, 18, fo. 162v. See also OeStA, HHStA, OA, 56, fasz 67c, fos. 29v-30r.

${ }^{45}$ Dedem van Gelder, Mémoires, pp. 23-4.

${ }^{46}$ Herbert to Cobenzl, Pera, 2 May 1780, OeStA, HHStA, Staatenabteilungen, Türkei V, 18, fo. 83r; Charalampos Minaoglou, 'Ottomans, Habsburgs, Romanovs, and French revolutionaries: whom were the Phanariots loyal to?', in Dimitris Samatopoulos, ed., Balkan nationalism(s) and the Ottoman empire, I: National movements and representations (Istanbul 2015), pp. 63-74. See also Christine Philliou, 'Communities on the verge: unraveling the Phanariot ascendancy in Ottoman governance', Comparative Studies in Society and History, 5 (2019), pp. 151-81.
} 
My Tassara sister is what one might call a wicked woman; she is vain, annoying, false, and through her intrigues, she controls and governs her husband who is as vain as she is...They both assumed, ridiculously, that the internunciature was theirs by right, and that I took it away from them. Had he not fallen for this idea, Tassara, on his own, would be quite a nice boy. But he acts indecently because of the grief caused by this plague [of a woman]. All the females around him push him to act in this way, despite all I do for them: for, as I want to show them my current affluence, I house and feed Tassara, his wife, his daughter, three servants. I keep this entire family warm, and give them light and food. I do so even for the Weingarbe and the servants. They are all ungrateful, but I would not care if it did not lead to daily inconveniences from which I would like to be free...I beg you to find a way to have them removed soon, and to their advantage. ${ }^{47}$

The misogynistic tone of Peter Herbert von Rathkeal's prose underscores his determination to make his patron understand the harmful effect that his sister was having on the smooth running of the Palais d'Allemagne. He succeeded in obtaining a promotion for Tassara in Vienna and kept him among his clients. ${ }^{48}$ Herbert von Rathekeal did, however, intend to free himself from his dependence on his mother's family. As early as 1782, he planned to reconfigure his influence and described his daughters Fanny and Constance as future political assets. ${ }^{49}$ It was for this reason that Constance continued to live in the Palais d'Allemagne on a partial basis after her marriage in 1798.

To a certain extent, the role of women in the political life of Pera was very similar to that of women in the major European courts such as those of Paris, Madrid, or Vienna. They provided their clients with introductions, recommended, and protected them. However, their influence in Pera was probably even more significant due to the fact that the diplomatic environment was deeply dependent on the urban society. Studying diplomacy in Pera on an embassy by embassy basis, as is still too often the case, limits the scope of the enquiry. The networks that, thanks to women, interwove and interlinked the different embassies, were at the very core of Pera's political society. They determined its dynamics and social codes.

\footnotetext{
${ }^{47}$ Herbert to Cobenzl, Pera, 17 June 1780, OeStA, HHStA, Staatenabteilungen, Türkei V, 18, fos. 97v-98r, translated from French.

${ }^{48}$ Vezeichniß des gesamten für das Orientalische verwendeten Personels. in Wienn, OeStA, HHStA, OA, 56, fasz 67c, fos. 27-28v. See also Norman A. Stillman, 'A new source for eighteenth-century Moroccan history in the John Rylands University Library of Manchester: the Dombay papers', Bulletin of the John Rylands Library, 57 (1975), pp. 463-86; Jan Schmidt, 'Franz von Dombay, Austrian dragoman at the Bosnian border, 1792-1800', Wiener Zeitschrift für di Kunde der Morgenlandes, 90 (2000), pp. 79-80.

${ }^{49}$ Herbert to Cobenzl, Pera, 11 Mar. 1782, OeStA, HHStA, Staatenabteilungen, Turkei V, 18, fo. 225r; Herbert to Cobenzl, Dobra, 14 Aug. 1779, ibid., fo. 14r; Herbert to Cobenzl, Pera, 17 Nov. 1779, ibid., fo. 33r; Herbert to Cobenzl, 25 Feb. 1782, ibid., fo. 222v; Spencer Smith to Grendville, Pera, 18 Mar. 1799, British National Archives, Foreign Office (FO), 78/21, fo. 207r-v.
} 


\section{IV}

In eighteenth-century Pera, women controlled access to a variety of economic and social resources and asserted themselves through an assumed, acknowledged, and confident libertinism. This libertinism can be defined by a critical distance from Roman Christian morality and by an independence of property and bodies that was not considered subversive, but rather was the norm. Women were respected and were raised in a dominant libertine culture based on the strong influence they could have on Pera's diplomatic society. ${ }^{50}$

Intellectual and sentimental independence constituted additional elements in the education and upbringing of the female offspring of Pera's diplomatic elite. Constance's independence resulted first and foremost from an education, and was fully endorsed by Peter Herbert von Rathkeal. As a radical reformer, Peter Herbert von Rathkeal expressed praise for the education he wanted to give his daughters. Somewhat ironically, he wrote that 'because they are my daughters, they must become great bitches [gârces],' ${ }^{51}$ that is to say shrewd independent women skilled in imposing their own agendas on a maledominated political society. Marriage was conceived of as an objective alliance between two parties who pooled their resources and benefited respectively. Thus, marriage here did not imply a shared or exclusive marital life. During the early years of their marriage, Constance accompanied her husband on his missions to Istanbul, Paris, and Wurzbach. However, Spencer Smith failed to excel in his diplomatic career and in 1807 was elected to the House of Commons. Constance did not follow him to England, instead moving to Vienna. Until her death in 1829, the spouses maintained a long-distance, cordial, and even affectionate relationship. However, it was understood that for the respective careers of both spouses, and their individual and family prosperity, this was an open relationship. ${ }^{52}$ The freedom that Constance asserted as an adult earned her harsh criticism from Dedem van Gelder, who castigated her 'éducation manquée' (incomplete education). Lord Byron realized what was at stake in the freedom that Constance had asserted in becoming his lover. From Malta he wrote: 'Since my arrival here I have had scarcely any other companion', adding 'I have found her very pretty, very accomplished, and extremely eccentric. Buonaparte is even now so incensed against her, that her life would be in danger if she were taken prisoner a second time' (Figure 1). ${ }^{53}$

\footnotetext{
${ }^{50}$ Michel Delon, Le savoir-vivre libertin (Paris, 2000); Ruth Dawson, 'Eighteenth-century libertinism in a time of change: representations of Catherine the Great', Women in German Yearbook, 18 (2002), pp. 67-88; Margot Finn, 'The female world of love \& empire: women, family \& East India Company politics at the end of the eighteenth century', Gender \& History, 31 (2019), pp. 7-24. See also Adam Komisaruk, 'Libertinism', in Clara Tuite, ed., Byron in context (Cambridge, 2019), pp. 124-30.

${ }^{51}$ Herbert to Cobenzl, Pera, 11 Mar. 1782, OeStA, HHStA, Staatenabteilungen, Türkei V, 18, fo. $225 r$.

${ }^{52}$ Constance Spencer Smith to William Sidney Smith, Vienna, 28 May 1827, RUL, WRC, MS 267, 1/25; Trébutien, Notice necrologigue, pp. 11-13.

${ }^{53}$ RUL, WRC, MS 267, 1/25.
} 


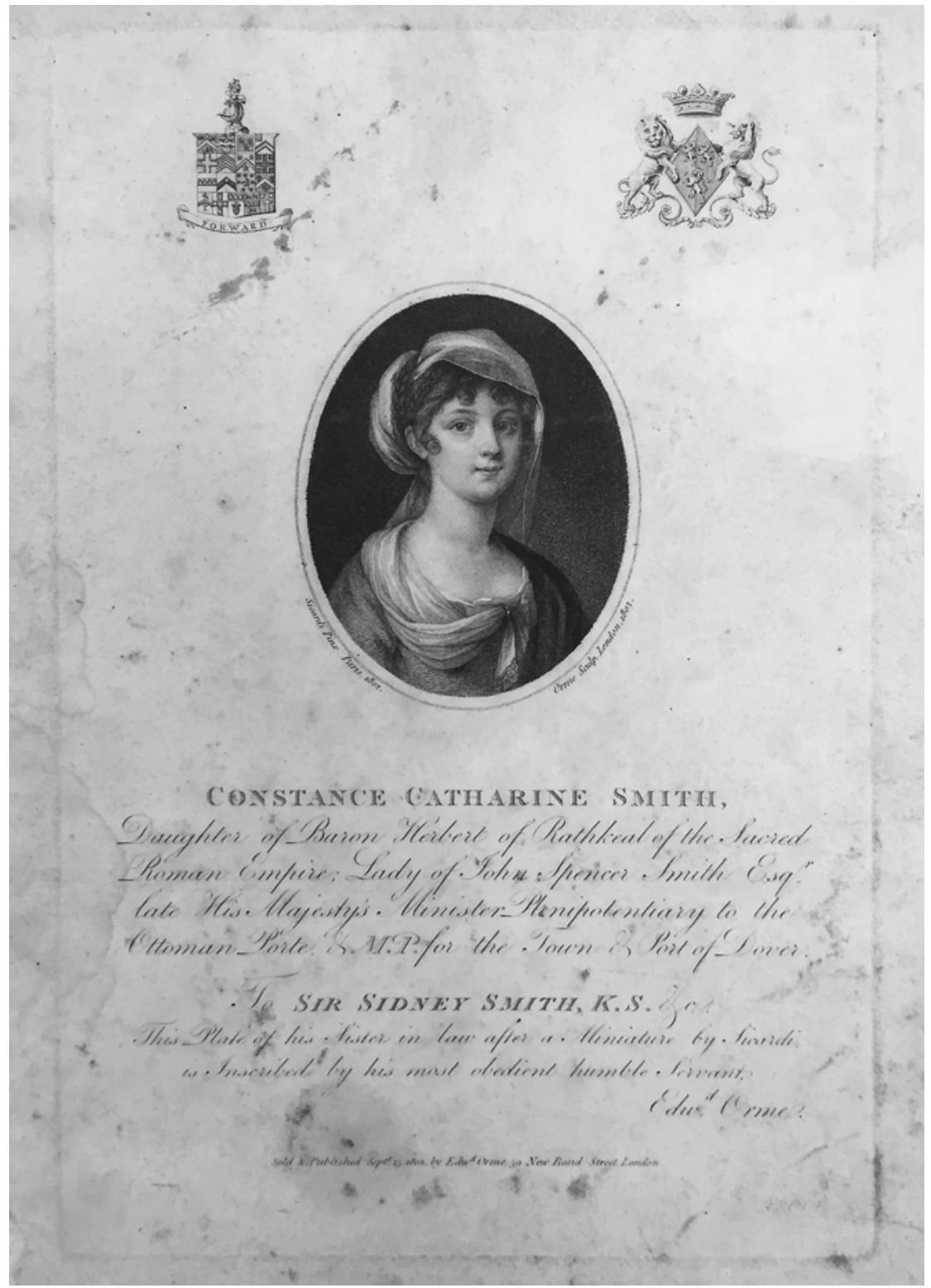

Figure I. Portrait of Constance Smith (born Herbert von Rathkeal) offered to William Sidney Smith and printed in London by Edward Orme from a model drawn in Paris by Louis Marie Sicard in 1802 (Rice University Library, Woodson Research Center, MS 267, I.23).

William Sidney Smith II-Constance and John Spencer Smith's sonestablished a rich family memory of his mother in the mid-nineteenth century that included elements evoking her emotional and sexual freedom. He 
documented the romance between her and Byron, and even conducted genealogical research to show that the two families were related. Later, in the 1810s and 1820s, William learned that when she was living in Vienna, Constance had frequented the same orientalist circles that she had grown up among in Pera, notably with Joseph Hammer von Purgstall and Thomas Chabert. From Vienna, Constance also managed the family's financial assets, and eventually moved in with the Puthon couple. In society, Jean-Baptiste Puthon introduced Constance as his wife's lover. Following Mrs Puthon's death, Constance lost the will to live and died shortly after. Jean-Baptiste buried the two women in the same vault in the Währinger cemetery in Vienna. In addition, Puthon had a verse by Byron engraved on the tomb, thus publicly endorsing the relationship between the two women. The social acceptance of Constance's polyamorous and pansexual life was a reflection of her influence in the different milieus in which she belonged. ${ }^{54}$

Like many other women from Pera, not being exclusively attached to anyone was a way to maintain, if not to increase, such influence. For example, Hammer wrote a detailed portrait of his close friend Caterina Marini, in 1803. Caterina was the illegitimate granddaughter of the former Internuncio Johann Franz De Paula von Thugut, and the daughter of the Neapolitan embassy secretary Jacopo de Marini. She was the lover of the Russian ambassador Viktor Pavlovich Kochubey, then the unofficial partner of the Neapolitan representative von Ludolff, Catherine Chabert's son. When von Ludolff died in 1803, Caterina became a free agent, and this gave rise to much competition within the diplomatic corps as contenders vied for the access she could provide to the networks at whose crossroads she was located. Caterina owned a property north of the village of Belgrade overlooking the Black Sea, where she maintained a salon frequented by embassy subordinates such as young students in oriental languages and interpreters seeking to make themselves known and build their careers. Hammer, notably, showed a deep respect for Caterina's moral freedom. Much courted for both her personal qualities and her entries into Habsburg, Romanov, and Bourbon diplomatic circles, ${ }^{55}$ Caterina cultivated this competition in order to preserve her leverages. Hammer noted:

Madame Marini was by far the wittiest woman in Pera, she was funny, simple and natural. Sometimes her parties were very drastic. Bielefeld and I courted her together and she called us 'les adorateurs en commun'. I spent many evenings with her in witty and entertaining conversations and many mornings on horseback riding after her dairy.

Several times a month I organized large riding parties with other ladies and gentlemen, often ten to fifteen couples; Madame Marini, a good and courageous rider, was never absent. She gave me confidential

\footnotetext{
${ }^{54}$ Ibid. Jean-Baptiste Puthon was the son of a textile trader and the director of the Austrian National Bank. In the year of Constance's death, he financed the development of infrastructure that facilitated river trade between Vienna and the Ottoman empire; see Genealogisches Jahrbuch, 36-8 (1996), p. 119.

${ }^{55}$ Hammer, Erinnerungen, pp. 143-4.
} 
information about her well-known loves, which did not deter me from following the same tracks. ${ }^{56}$

The libertinism of influential women such as Caterina Marini and Constance Herbert von Rathkeal allowed them to keep their social influence intact by not belonging to any man. They occupied a central position in the social game due to the resources to which they decided whether or not to provide access. The role they played in Pera was again very similar to that held by aristocratic women in London and Paris. ${ }^{57}$ Like the other Habsburg students in oriental languages, Hammer sought to find himself a wife among the Roman Catholic families of Pera. For this, he attended the salon of Caterina Marini in Belgrade and the society of Caterina Hübsch von Grossthal in the Princes' Islands. Not only were these the circles in which the fame of ambitious young men was built, these salons were also places where information was exchanged and where the intellectual identity of the men who frequented them was established, asserted, and recognized by women. Indeed, Hammer acknowledged that the women of Istanbul played an absolutely essential role in the construction of his knowledge and particularly in language learning. The social function of libertinism within Pera's diplomatic milieu gained acceptance through adherence to a philosophical ideal of freedom. This ideal was radicalized by the expatriation of members of Pera's political society and the religious diversity of Istanbul, often described in the eighteenth century as a source of tolerance. ${ }^{58}$

Generally speaking, the memoirs of Joseph Hammer von Purgstall constitute a particularly rich resource for exploring the place of women in Pera's political society. Hammer's gaze was that of an enlightened man from a bourgeois family, who owed his social advancement to the study and service of the Habsburg monarchy. Hammer himself embraced the radical positions of Peter Herbert von Rathkeal on the subjects of religion and politics. His relationships to women in Pera were marked by his social background and political ideal. In 1799, when Peter Herbert von Rathkeal went to the seaside village of Büyükdere (Sarıyer), Hammer mentioned the whist games that the Internuncio organized with an English agent named Aide and that:

Aide had a house full of partly fully-grown and partly half-grown girls, whose mother from Aleppo, a real Arabic woman of a more advanced age, kindly granted my request to read Arabic with me. Through her I

\footnotetext{
${ }^{56}$ Ibid., p. 144, translated from German.

${ }^{57}$ Antoine Lilti, Le monde des salons: sociabilité et mondanité à Paris au XVIIIe siècle (Paris, 2005); Susanne Schmid, British literary salons of the late eighteenth and early nineteenth centuries (London, 2013). See also Brian Cowan, 'English coffeehouses and French salons: rethinking Habermas, gender and sociability in early modern French and British historiography', in Angela Vanhaelen and Joseph P. Ward, eds., Making space public in early modern Europe: performance, geography, privacy (London, 2013).

${ }^{58}$ Hammer, Erinnerungen, pp. 43, 143-4; Eric Dursteler, “'Of women learned in the tongues": language, gender and domestic space in the early modern Mediterranean', Renaissance Quarterly (forthcoming).
} 
got to know Antar ${ }^{59}$ and read it with her regularly for a few hours in the morning.

My morning hours were now devoted to office work, reading Antar and conversations with the old woman, and my evening hours were spent walking along the quay of Büyükdere with young girls. So I learned Arabic in the morning and Modern Greek in the evening.

The reading of Antar was instructive for me with regard to Arabic customs, in that it completely penetrated me with the spirit of Arabic chivalry, and I found many points of contact with European chivalry, to my astonishment...I always told my patron [Peter Herbert von Rathkeal], who was very receptive to everything scientific, about such remarks, and my poem about the liberation of Acre, which was dedicated to his daughter, put me so much in his grace and favour that he gave me permission to wear Turkish clothes three days before the end of my stay in the country, which had been extended from two to four weeks, and to leave for Aleppo in the spring. ${ }^{60}$

Pera society acknowledged and accepted the libertine status of influential women. The diplomatic corps in Pera was dependent on Pera's social elite to such an extent that their agents had to adjust and adapt to the norms and values of its Roman Catholic families, in which women played a key role. To some extent, the diplomatic corps accommodated this because the political role played by women in Pera was not fundamentally different from that played by female aristocrats in Paris, Madrid, or Naples. ${ }^{61}$ Moreover, the period of the Atlantic Revolutions was not in itself favourable to women, and the Roman Catholic nobility of the various diplomatic corps in Istanbul may have discerned in Pera society an opportunity to maintain a longstanding order in which women were influential and where their status as political actors was recognized. Paradoxically, the Roman Catholic church's weak moral control over the believers in Pera facilitated, more than elsewhere in the European Roman Catholic world, the affirmation of an important diplomatic and social role for women. In addition, the Islamophilia that characterized certain radical currents of thought in the Enlightenment allowed the men and women of the diplomatic corps to live a certain moral ideal in Istanbul. This was based on the ideals of freedom and tolerance, and was particularly promoted among the radical Habsburg reformist elites, such as those who operated out of the Palais d'Allemagne in Pera from 1779 onwards.

\footnotetext{
${ }^{59}$ Antarah ibn Shaddad al-Absi was a sixth-century Arab poet and knight. A famous twelfthcentury chivalric novel told his story and was one of the most important contributions to medieval Arabic and Syrian literature. In the nineteenth century, Antar became a romantic hero mentioned by several poets such as Lamartine.

${ }^{60}$ Hammer, Erinnerungen, p. 42, translated from German.

${ }^{61}$ Madame de Pompadour 'was a nodal point of contact for foreign representatives, as well as a mediator', Eva Katherine Dabe, 'Die Königliche Mätresse als Diplomatin. Madame de Pompadour im Dienst der französische Krone', in Thiessen and Windler, eds., Akteure der Außenbeziehungen, p. 291. See also Oliván Santaliestra, Mariana de Austria, pp. 139-43.
} 
Studying the women of the Palais d'Allemagne in Istanbul sheds light on the fact that the diplomatic corps was organized in households. These households were structured around the central couple of the ambassador and his wife. Both were involved in the running of the embassy. They defended the interests of their respective courts, parties, and friends. This couple formed the core of a polynuclear family spanning three generations and extending to the householders. Within the household, the polynuclear family lived with its protégés, i.e. the agents (secretaries, interpreters, and clerks) and their wives who moved into the Palais d'Allemagne. These protégés became symbolically integrated into the family through the patronage of their children or the involvement of the central couple in securing their marriage. The household was connected to the city and to political society through the servants attached to the service of the various female family members. Wives and children also moved from one embassy to another on a daily basis as part of a sociability based on personal ties and shared private economic or political interests. In the late 1790s, this led to a quasi-amalgamation of the Habsburg and British diplomatic corps.

As a micropolis, the Palais d'Allemagne, like other diplomatic corps, was faced with tensions related to the permanent arbitration that the ambassador had to undertake between individual interests, the interests of a court, and other third-party interests. Women in the Palais d'Allemagne therefore constituted valuable resources that the ambassador could mobilize to help achieve his political and economic aims. They sometimes took on official diplomatic roles or became heads of parties, which often took the form of a family or a household, whose interests they represented and defended before the ambassador. The Palais d'Allemagne could therefore be the setting for conflicts between the different parties that had the potential to hinder the smooth running of the embassy. Nevertheless, conflicts had to be acknowledged by the ambassadors as an acceptable risk, since the presence of such parties in the embassies was indispensable to them.

Pera was a political society whose social life revolved around influential and independent women whose networks shaped and contributed to the education and socialization of an international elite. These women participated in a hybrid social life that was specific to embassies on the one hand and the private life of subordinate agents on the other. They cultivated networks, access to which was gained by attending circles and salons. They facilitated marriages, strategically distributed information specific to Pera's political milieu, and participated as friends or teachers in the intellectual and linguistic training of young members of the Roman Catholic diplomatic corps in Istanbul. They maintained and developed an intellectual, moral, and sexual libertinism that guaranteed their independence and corresponded to a certain aristocratic ideal that was being challenged in Europe and the Atlantic world during the revolutionary period.

This article demonstrates the importance of establishing a social history of diplomacy. It advocates multiplying the use of sources of different kinds, in 
particular private archives and parish archives, and more generally the archives of family history, urban history, and gender history. This new diplomatic history must continue to be demasculinized, de-Westernized, and should constantly question the categories it mobilizes in order to remain as close as possible to the social realities it intends to describe and analyse.

Acknowledgements. This article is deeply indebted to E. Natalie Rothman and the Ottoman and Turkish studies seminar of the University of Toronto, and to Naoko Shimazu for their early and generous feedbacks. I am also very grateful to Lucien Bély and the Sorbonne Université seminar 'Histoire internationale de l'Europe et du monde', to Eric Dursteler and the Renaissance Society of America, and to Randi Deguilhem and the Collège des Bernardins seminar 'Femmes et religions en Méditerranée'. It finally received the support of the Sciences Po Migration \& Diversity (MiDi) interdisciplinary working group.

Cite this article: Do Paço D (2022). Women in Diplomacy in Late Eighteenth-Century Istanbul. The Historical Journal 65, 640-662. https://doi.org/10.1017/S0018246X21000479 